\title{
A Lexical Analysis of Social Software Literature
}

\author{
Loay ALTAMIMI \\ Dept. of Management Information Systems \\ AL-Zaytoonah University of Jordan \\ 1.altamimi@zuj.edu.jo
}

Social software are today more prevalent in organizational context, providing new ways for work and giving web users new opportunities for interaction and collaboration. This review aims to gain insight into the extent of available scholarly and professional literature on these new tools and into interests in this field. The analysis of the 5356 collected articles includes type of publication, year of publication, source, keywords in articles' titles and abstracts. The study here adopted a systematic approach for the literature review, that is, the principle of Lexical Analysis.

Keywords: Lexical Analysis, Literature Review, Social Software, Web 2.0

\section{1} Introduction

Information and communication technologies like the web have permeated the various aspects of organizational life offering many possibilities of work [1]. Meanwhile, knowledge is growing and transferring around the globe in an accelerating pace [2]. Ideas are no longer confined just to a firm's internal boundaries. Knowledge can also be sourced from the external environment [3]. Moreover, knowledge generation and transfer is a product of social exchange [2], [4]. Social interaction and collaboration are important for the enlargement of an individual's knowledge within an organization and thus initiating the process of organizational knowledge creation [5]. Social software is at the heart of the web new generation commonly known as web 2.0 [6], [7]. Web 2.0 technologies are rewriting the rules of social interaction, and the way business is conducted. New and ingenious methods of social interaction across geographic borders and industry silos are being created, as cited in [8]. Web 2.0 and social software applications such as blogs and wikis, are increasingly being utilized as ways for businesses to collaborate and share information with employees, customers, partners and suppliers'[7].

The term social software was popularized by Clay Shirky, starting in about 2002 [9]. As to the term Web 2.0 became notable after the first O'Reilly media Web 2.0 conference in 2004. The reference [10] defines social soft- ware as software that supports group interaction. According to [11], 'Web 2.0 is the network as platform, spanning all connected devices; Web 2.0 applications are those that make the most of the intrinsic advantages of that platform: delivering software as a continually-updated service that gets better the more people use it, consuming and remixing data from multiple sources, including individual users, while providing their own data and services in a form that allows remixing by others, creating network effects through an "architecture of participation", and going beyond the page metaphor of Web 1.0 to deliver rich user experiences'. However, as in the context of this paper, the two terms social software and web 2.0 are sometimes used interchangeably e.g. [12], [13], [14]

\section{Background \& Objective}

There are many definitions of the term social software in addition to the concise one by Shirky indicated in the introduction. For instance, the more elaborate definition by [15] states that, social software refers to "various, loosely connected types of applications that allow individuals to communicate with one another and to track discussions across the Web as they happen'. For more definitions see [14].

Social software is becoming increasingly important and popular in the present society. Today, these tools are more prevalent in organizational context, providing new ways for 
work and giving web users new opportunities for interaction and collaboration [16], [17], [18], [19]. The Gartner report 2011 indicates that, enterprises continue to invest in social software [20]. A study from the [21] shows a very significant increase in the use of Web 2.0 applications within companies. The momentum of these emerging tools is also manifested in the recent term of Enterprise 2.0 coined by Professor Andrew McAfee to highlight the fact that smart companies are embracing Web 2.0 technologies, as well as the underlying approach to collaboration and creation of content [22]. Another example is the adoption and the spreading of the social software bottom-up sharing philosophy in e-learning initiatives and educational context cf. [23], [24]. Indeed, these technologies have gained interest for both, for work as well as leisure purposes, and there would appear to be a blurring of the boundaries between the two [25].

There are a number of characteristics that are presumably the drivers behind the popularity of social software. The most important of these include, sharing, interacting [26], knowledge sharing is voluntary [27], ease of use, support for social networks, usergenerated content, enforcing much less sense of hierarchy than in the real world so anyone can provide feedback or comments to anyone else and one person can be at the same time part of several networks [14], [28], [29], and establishing of weak ties, which refer to acquaintances with less social involvement, more superficial and on a smaller, less intimate basis [30]. Another essential characteristic that has been referred to recently in the literature is what is called "Nutzungsoffenheit", which implies that it is hard to predict how a platform will be appropriated [31] and whereby, technology and its set of features do not precipitate its forms of usage [32].

In light of the growing attention given to social software in the last decade or so; the aim of this review is to systematically explore the evolution of literature since the emergence of social software and Web 2.0 technologies. It also attempts to identify main publications, tools addressed and significant trends in the scholarly and professional social software literature.

\section{A Review of Social Software Literature Reviews}

A number of reviews on social software literature were found

and all of them were published in the period between 2007 and 2012. These are presented here in chronological order to take the reader from the oldest to the most recent.

The review of [33] aimed at gaining insight into the implications of the proliferation of social Software and its consequences for the hotel industry. As to the study by [13], it discussed literature on the impact of social software on the library community.

Another two articles were in the year 2009. One of them is [34], which provides a review of literature on the role of Web 2.0 or social software tools in education. The other one was by [8] and it presents the benefits and perceived risks associated with electronic social networking in organizations.

The reference [35], explored renewed concerns about the reliability of online health information in light of the increasing popularity of web applications that enable more enduser-generated content ("web 2.0"). Meanwhile, [36] synthesizes and analyzes academic and practitioner-oriented literature to provide a definition of the term Web 2.0 and to categorize previous literature and uncover opportunities for future research. Lastly, in this review of literature reviews, [37] dealt with Web 2.0 technologies in an educational context to discover a new image of learners.

The table 1 sums up the articles included in this review of reviews, with respect to, the period covered, number of articles analyzed, type of sources, search databases utilized, search keywords used and the focus area of the literature review.

The present paper adds to prior studies and contributes in the following ways. It is concerned with literature published in the areas of business and management, and it covers the entire period that extends from the beginning of the emergence of social software and 
Web 2.0 technologies to the year 2012. It also utilizes a broad range of keywords and covers a wide range of social software tools as well as it includes a large number of articles (5356 scholarly and professional articles). Furthermore, the study here adopted the principle of lexical analysis for the literature review, which is a systematic approach that is not used in any of the previous reviews. This approach is simple and enables the treatment of large bodies of information. It consists of applying quantitative analysis to the graphical forms present in a text; a "graphical form" represents a continuous character string containing no separating character. Studying the statistical distribution of these forms enables the production of summaries and the identification of "significant" trends [38], [39].

Table 1. Summary of Social Software Literature Reviews

\begin{tabular}{|c|c|c|c|c|c|c|}
\hline Reference & Period & $\begin{array}{c}\text { No of } \\
\text { Articles } \\
\end{array}$ & $\begin{array}{l}\text { Type of } \\
\text { Sources } \\
\end{array}$ & Databases & Keywords & $\begin{array}{r}\text { Focus } \\
\text { Area } \\
\end{array}$ \\
\hline [33] & N/A & N/A & $\begin{array}{c}\text { Journals, } \\
\text { Periodicals, } \\
\text { Blogs, } \\
\text { Message- } \\
\text { Boards \& } \\
\text { Consumer } \\
\text { Review } \\
\text { Sites. }\end{array}$ & N/A & N/A & $\begin{array}{c}\text { Hotel } \\
\text { Industry }\end{array}$ \\
\hline [13] & $\begin{array}{l}\text { Up } \\
\text { Until } \\
2007\end{array}$ & $\mathrm{~N} / \mathrm{A}$ & $\mathrm{N} / \mathrm{A}$ & $\begin{array}{c}\text { LISA, LISTA \& } \\
\text { ERIC }\end{array}$ & N/A & $\begin{array}{c}\text { Library } \\
\text { Community }\end{array}$ \\
\hline [34] & $\begin{array}{c}\text { Up } \\
\text { Until } \\
2009\end{array}$ & N/A & $\mathrm{N} / \mathrm{A}$ & N/A & N/A & Education \\
\hline [8] & N/A & N/A & $\begin{array}{c}\text { Journal } \\
\text { Articles, } \\
\text { White } \\
\text { Papers, } \\
\text { Popular } \\
\text { Media \& } \\
\text { Books }\end{array}$ & N/A & N/A & $\begin{array}{l}\text { Electronic } \\
\text { Social } \\
\text { Networking } \\
\quad \text { in } \\
\text { Organisations }\end{array}$ \\
\hline [35] & $\begin{array}{l}2006- \\
2008\end{array}$ & $\begin{array}{c}56+6 \\
\text { Blogs }+ \\
1 \text { Wiki }\end{array}$ & $\begin{array}{c}\text { Journals, } \\
\text { Conference } \\
\text { Proceedings, } \\
\text { Trade Publi- } \\
\text { cations } \\
\& \text { Book } \\
\text { Series + } \\
\text { Blogs + } \\
\text { Wiki }\end{array}$ & $\begin{array}{l}\text { Scopus, } \\
\text { Elsevier } \\
\text { PubMed \& } \\
\text { Google } \\
\text { Scholar }\end{array}$ & \begin{tabular}{|c|} 
"Web 2.0," \\
"Web Log," \\
"Weblog" \\
"Blog" \\
Singularly \& \\
In \\
Combination \\
With \\
Patient, Health \\
\& Medicine. \\
"Second Gener- \\
ation Web," \\
"Wiki" "Health \\
2.0," \\
"Medicine 2.0"
\end{tabular} & $\begin{array}{l}\text { Online } \\
\text { Health }\end{array}$ \\
\hline [36] & $\mathrm{N} / \mathrm{A}$ & $\begin{array}{c}114 \\
\text { Articles }\end{array}$ & $\begin{array}{l}\text { Academic, } \\
\text { Crossover } \\
\text { (Outlets at }\end{array}$ & $\begin{array}{l}\text { EBSCO Busi- } \\
\text { ness Source } \\
\text { Complete And }\end{array}$ & $\begin{array}{l}\text { Variants of } \\
\text { "Blog" Or } \\
\text { "Wiki", }\end{array}$ & $\begin{array}{l}\text { Informtion } \\
\text { Systems } \\
\text { (IS) }\end{array}$ \\
\hline
\end{tabular}




\begin{tabular}{|c|c|c|c|c|c|c|}
\hline & & & $\begin{array}{l}\text { Intersection } \\
\text { between } \\
\text { Academia \& } \\
\text { Practice), \& } \\
\text { Practitiner }\end{array}$ & $\begin{array}{l}\text { ABI/INFORM } \\
\text { Proquest }\end{array}$ & $\begin{array}{c}\text { "Social } \\
\text { Boomarking" } \\
\text { or "Social } \\
\text { Computing", } \\
\text { "Facebook" } \\
\text { or } \\
\text { "YouTube" }\end{array}$ & \\
\hline [37] & $\begin{array}{l}2006- \\
2010\end{array}$ & $\begin{array}{c}181 \\
\text { Articles }\end{array}$ & $\begin{array}{c}\text { International } \\
\text { Journals }\end{array}$ & $\begin{array}{c}\text { EBSCO, Pro } \\
\text { Quest \& } \\
\text { Google } \\
\text { Scholar }\end{array}$ & $\begin{array}{l}\text { Web 2.0, } \\
\text { Learning } \\
\text { And E- } \\
\text { Learning }\end{array}$ & Education \\
\hline [8] & $\mathrm{N} / \mathrm{A}$ & $\mathrm{N} / \mathrm{A}$ & $\begin{array}{c}\text { Journal } \\
\text { Articles, } \\
\text { White } \\
\text { Papers, } \\
\text { Popular } \\
\text { Media \& } \\
\text { Books }\end{array}$ & $\mathrm{N} / \mathrm{A}$ & $\mathrm{N} / \mathrm{A}$ & $\begin{array}{l}\text { Electronic } \\
\text { Social } \\
\text { Networking } \\
\quad \text { in } \\
\text { Organizations }\end{array}$ \\
\hline
\end{tabular}

\section{Literature Search and Analysis Method}

A keyword search against two categories, the documents' title and abstract, was performed for scholarly and professional literature on social software, published in the period from $2002-2012$. The literature search aimed to be as comprehensive as possible. However, it was kept, as far as possible, focused on literature published in the areas of business and management. To this end, the search utilized Business source premier, Emerald and the subject area of Business, Management and Accounting in the database of ScienceDirect. The list of search keywords (Table 2) was developed with making use of [8], [13], [14],
[15], [36], [40], [41]. In this context, it is important to draw a distinction between social software and conventional groupware. Social software is the opposite of what groupware and other project- or organization-oriented collaboration tools were intended to be. Social software is based on supporting the desire of individuals to be pulled into groups to achieve their personal goals. The groupware approach places people into groups defined organizationally or functionally [15]. For more on the distinction between social software and groupware, see also [42], [27].

Table 2. List of Keywords

\begin{tabular}{|l|l|l|}
\hline - Web 2.0 & - Really Simple Syndication & $\bullet$ Web Forums \\
- Social Software & - Discussion Forums & $\bullet$ Social Bookmarking \\
- Mashups & - Social Tagging & $\bullet$ Folksonomy \\
- Information Markets & - Instant Messaging & - Collaborative Tagging \\
- Internet Forums & - Iowa Electronic & - Weblogs \\
- Massively Multiplayer Online & Markets & - Blogs \\
- Role Playing Games & - Prediction Markets & - Podcast \\
& - Discussion Boards & - Online Social Networks \\
& & \\
& &
\end{tabular}

The variables identified in the literature, for the purpose of the analysis were as follows, title, abstract, source, year and type of publication (scholarly coded as SP and profes- sional coded as PP). As indicated earlier, the principle of lexical analysis was employed for the purpose of this literature review. The use of lexical analysis enables the treatment 
of large bodies of information. When the corpuses are very large, the use of statistical procedures allows reducing the reading effort, taking advantage from the redundancy of the language. Another advantage is to use lexical entries to focus on some words or uses that would remain hidden by a classical reading. Statistics can thus help the reader curiosity and reinforce the discovery process. Lexical analysis changes the focus from the reading of the text to the reading of its lexical substitutes and thus speeds up the knowledge process [38], [39]. 'Lexical analysis offers a middle-ground between quantitative and qualitative analysis, being rapidly applicable to texts of all types, and giving a far more flexible interface between the tasks of data acquisition, analysis and interpretation. This approach is typified by the calculation of "word lexicons": lists of words and their corresponding frequencies in the corpus' [38]. The lexical analysis adhered to the following guidelines throughout:

- the two variables (Title, Abstract) are combined in a single variable
(Tit\&AbstCombined), in order to examine the title and abstract of each article simultaneously;

- the set of search keywords was developed into a dictionary (a dictionary is a list of terms which describes a certain theme), in which each keyword is grouped with its different variations and synonyms found in the corpus and is represented in the form (\#keyword), where (keyword) is the name assigned to the group (Table 3 ). That means that, a group (\#keyword) counted only once, if any of the variations and synonyms belonging to it, is repeated, and/or if found together, in the same article. This is done so that, frequencies are based on observations rather than on occurrences. In other words, frequencies herein represent the number of articles referring to a certain group or (\#keyword);

- the frequency of (\#keyword) is ignored if it is zero.

Table 3. Dictionary

\begin{tabular}{|l|l|}
\hline \#Wiki=Wikis=Wikipedia & \#Blogs=Weblogs= Bloggers= \\
\#MMORPGS = Massively Multi & Blogging=Blogosphere \\
player Online Role Playing Games & \#Discussion Forums= Internet Forums \\
= Online Massively Multiplayer & = Web Forums= Discussion Boards= \\
Computer Games & Online Forums \\
\#Podcast=Podcasting= & \#Instant Messaging=Chat Systems \\
Podcasts=Podcasters & \#Online Social Networks= Social \\
\#Prediction Markets= Iowa Electronic & Networking \\
Markets= Information Markets= & \#Mashups= Mashup \\
Decision Markets=Idea Futures & \#Bookmarking=Tagging=Folksonomy \\
\#RSS=Really Simple Syndication & \\
\hline
\end{tabular}

\section{Results and Discussion}

\subsection{Article type * Year of publication (Evolution of literature)}

After removing all duplicates, the total number of articles was 5356 articles. As shown in Fig. 1, the number of professional articles returned by the search process was significantly higher than the number of scholarly articles. This indicates the broad interest that social software and web 2.0 tools are attracting from the professional publications comparing to the scholarly literature. This might also be seen as indicative of the hype surrounding these technologies and thus could be regarded as supporting statements such as that of [7] that, 'the current stir surrounding web 2.0 is prone to so much hype', and of [43] that, 'there is currently much hype about a phenomenon known as Web 2.0 or social software', as well as of [44] that, 'Buzzwords such as web 2.0, social software, and enterprise 2.0 soon became the topic of market research reports. In these reports, the fashionableness of enterprise 2.0 was expanded 
through hyperbolic discourse typically associated with hype'.

However, looking at the picture, on a yearly basis Fig. 2, It is possible to clearly see that, there was a growing interest in social software that reached its peak in the year 2008 and 2010, in both professional, and also, although in a slower rate, in scholarly publications, respectively. Moreover, it is noteworthy that, from the year 2008 on, the gap in the number of articles, in favor of professional articles, began to narrow steadily and for the first time over the period 2002-2012, scholarly articles outnumbered professional articles in each of the last three years (2010/11 and 12). This could be a sign that the debate on social software is shifting to be more scientifically and scholarly oriented.

Having said that, the tide of interest in social software seems to be ebbing lately, as from the year 2009 on for professional publications, and over the last two years 2011/12 for scholarly literature, there was a noticeable and steady decrease in the number of articles on social software in both types.

\begin{tabular}{|c|r|r|}
\hline PP & 3395 & $63,4 \%$ \\
\hline SP & 1961 & $36,6 \%$ \\
\hline Total & 5356 & $100,0 \%$ \\
\hline
\end{tabular}

Fig. 1. Number \& percentage of scholarly \& professional articles

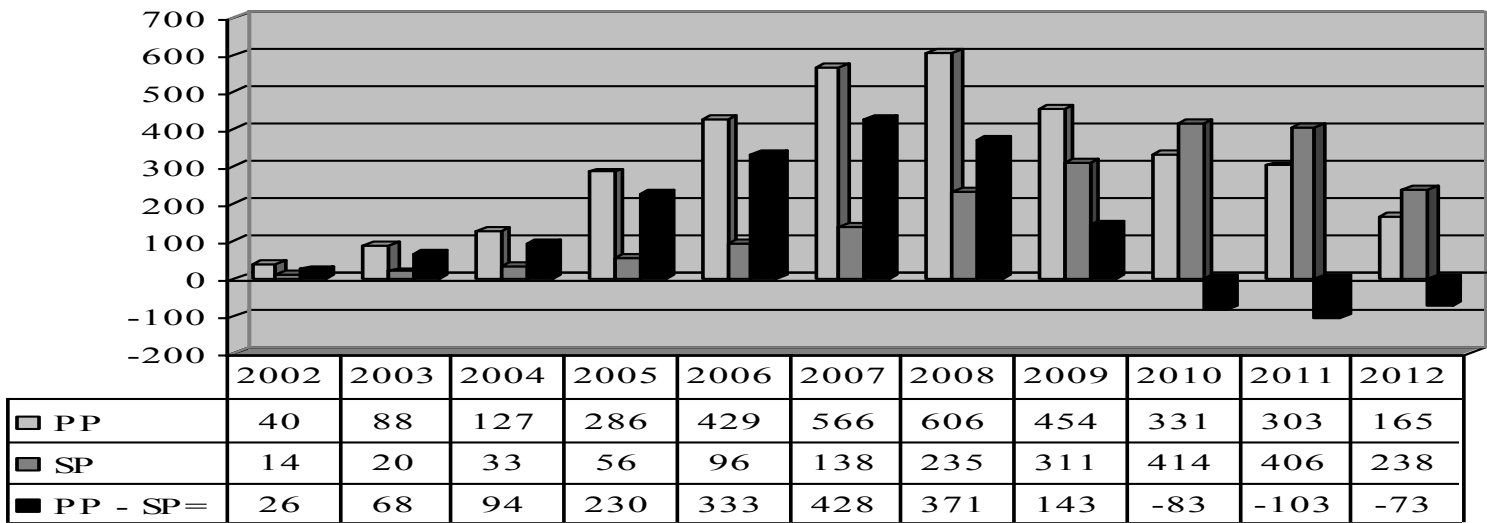

Fig. 2. Number of scholarly \& professional articles and difference between them per year

\subsection{The Use of Terminology in the Litera- ture}

Interestingly, the term web 2.0 was far more frequent in the literature than the term social software. This was also true in each of both types of literature, scholarly and professional, Figure 3. Additionally, when a search for each of these two terms was conducted in Google Scholar for the same period in this study (2002 - 2012), the term web 2.0 resulted in 49,500 articles, whereas, the term social software returned 17,300 results. This clear- ly suggests that, the first term is taking hold more than the latter one, although, as indicated earlier, the term web 2.0 became notable after 2004, whereas, the term social software was popularized in about 2002. However, it may be important here to emphasize that, as aforementioned, although the two terms are sometimes, or even often, used synonymously, as it is the case in this paper, yet, some others see a distinction and conceptual differences between Web 2.0 and social software $c f$. [45], [46]. 


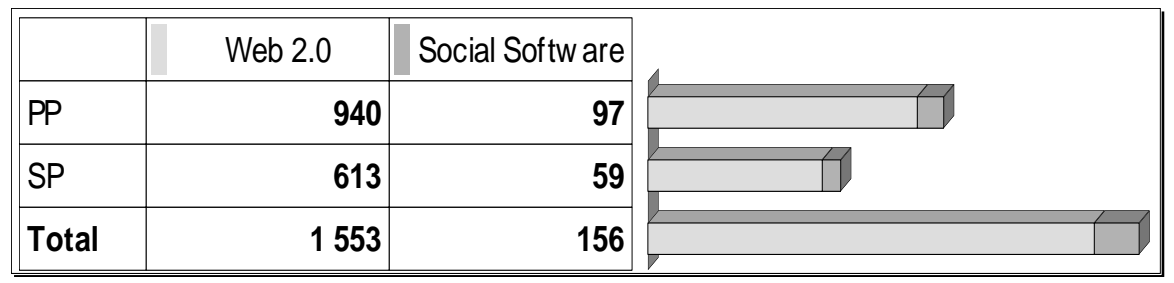

Fig. 3. Frequency of the terms "Social Software" \& "Web 2.0" / Publication type

\subsection{Frequencies of Social Software Tools in the Literature}

The results indicate that, \#blogs followed by \#online social networks, were the two types of social software tools most addressed in each of scholarly and professional literature. Perhaps, this is reflective of the huge spread and popularity that these particular two types of social software have enjoyed since their advent. For instance, with regard to blogs, [47] states that, 'blogs have gained massive popularity and have become one of the most influential web social media in our times'. In fact, a number of authors have pointed out that there's a growing body of research on blogs, e.g. [48], [49]. As for online social networks, they emerged as important areas of study as their popularity has exploded [50]. The reference [51] indicates that, the phe- nomenal growth of these tools like Facebook and Twitter and so on, has created many interesting research issues for the scientific community.

Other social software tools were, in varying degrees, less popular in the literature. In general, the rest of the results show a contrast between scholarly literature and professional publications in terms of dealing with the various types of tools. For Instance, among the eleven types of social software tools included in this study, \#Wikis and \#prediction markets were the third and the last in order, respectively, in professional publications, whereas, in scholarly publications, they were the forth and the seventh, respectively. All the results are shown in Figures $4,5$.

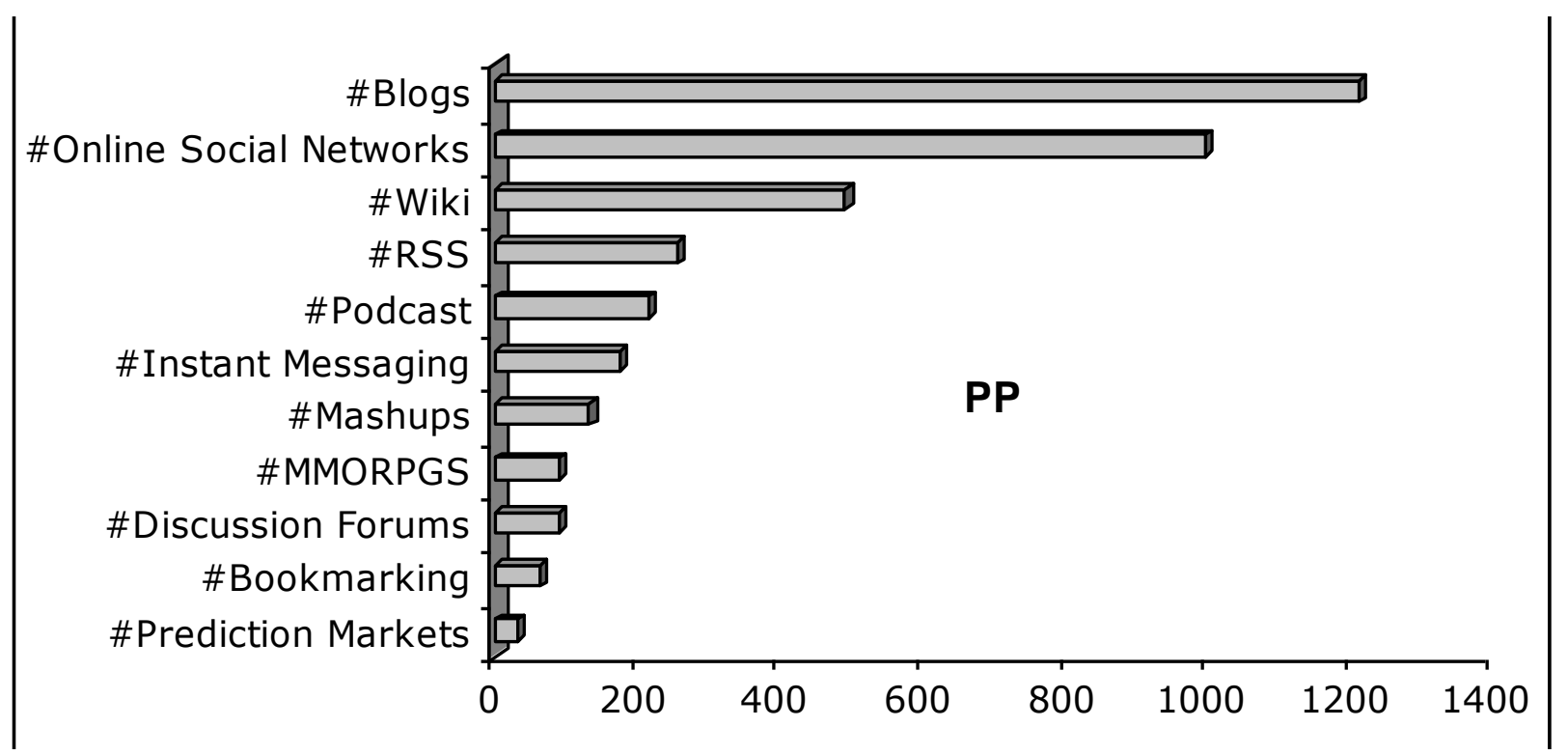

Fig. 4. Frequency of social software tools in professional literature 


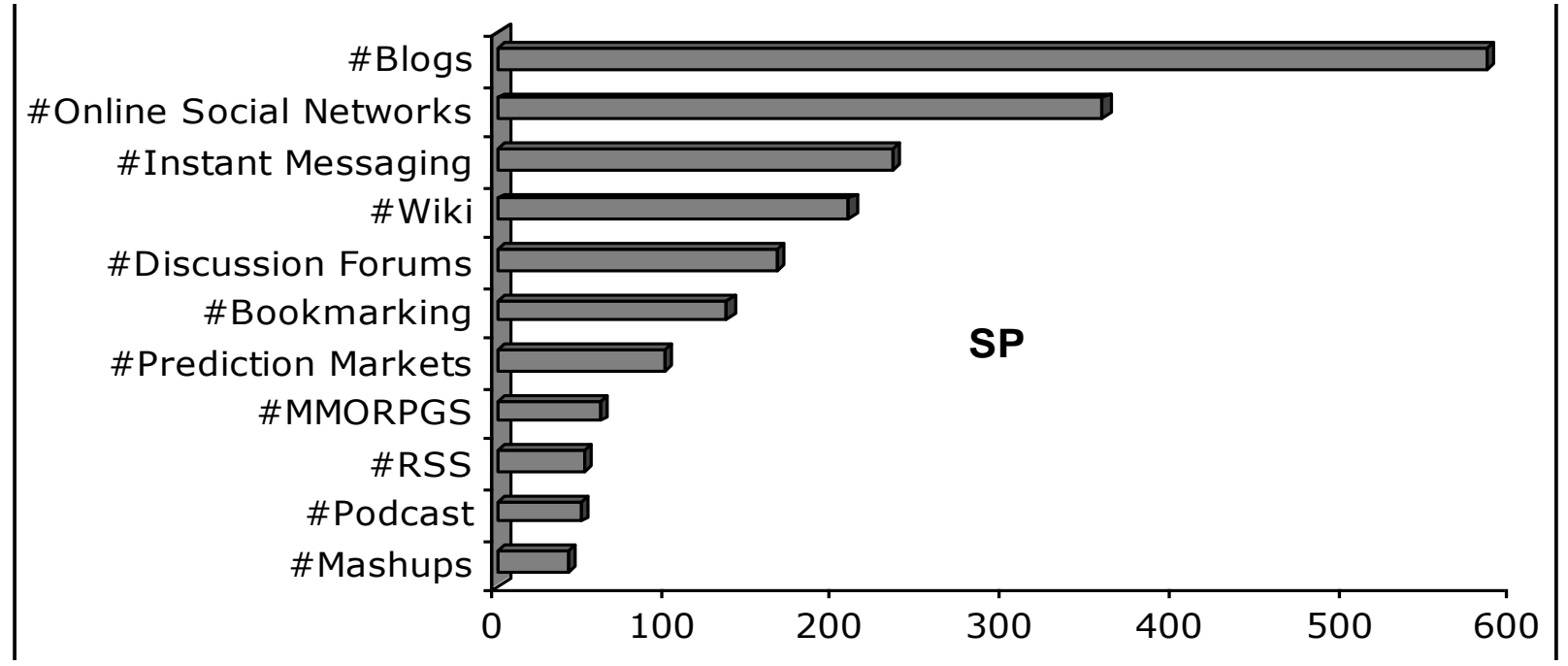

Fig. 5. Frequency of social software tools in scholarly literature

5.4 Characteristic Words in the Literature A search ignoring "tool words" (e.g. on, of, the...etc), words containing a number and words of fewer than two letters, was conducted on the variable (title\&abstractCombined), for the most charac- teristic words in articles by publication type. Looking at the results illustrated in Table 4 and Figure 6, they give a general feel of trends in addressing social software in each of the scholarly and professional literature

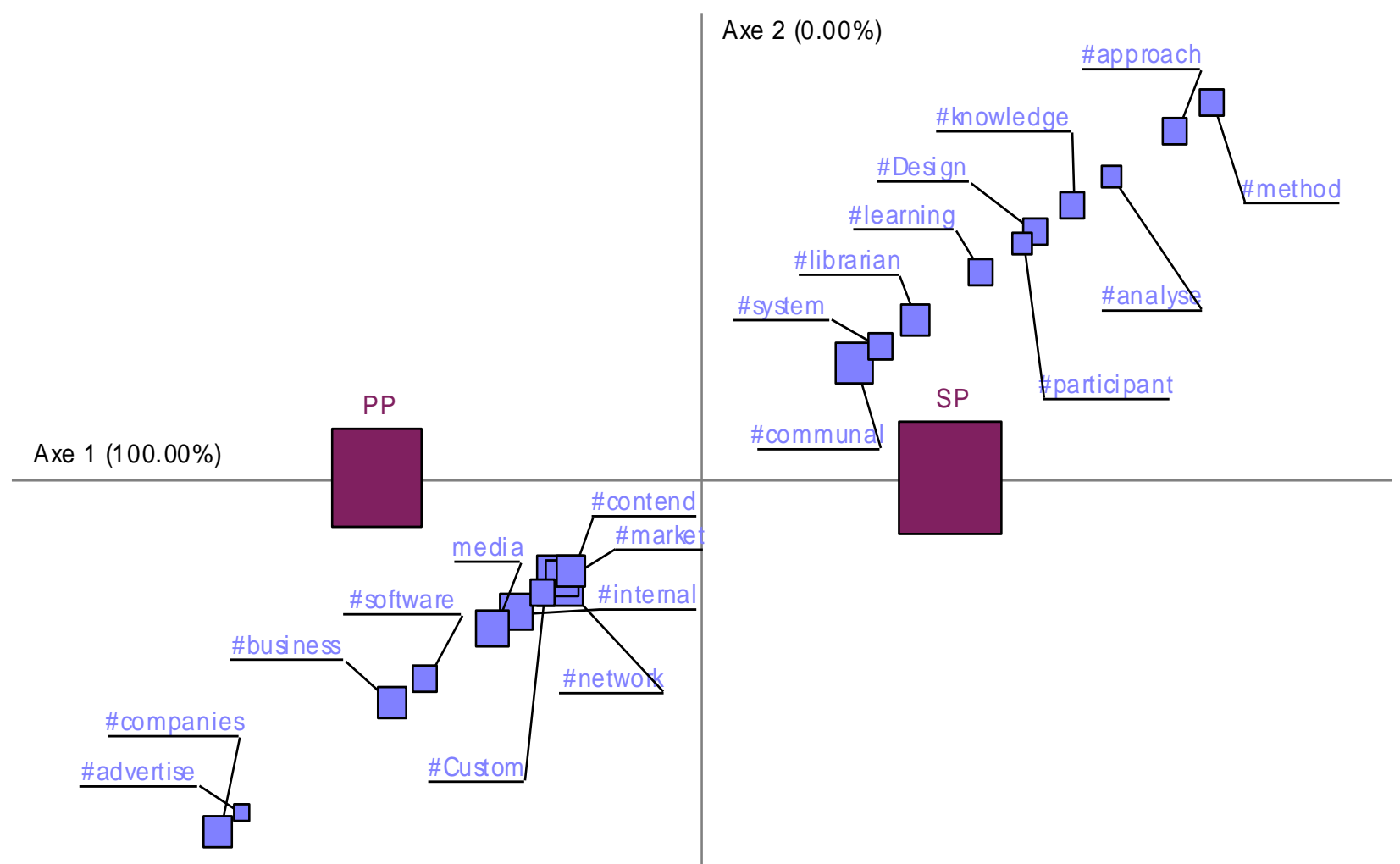

Fig. 6. Factor map of Characteristic Words by Type

- thresholds were set to show only terms with a minimum frequency of 5 for the whole corpus, and only 10 words per type category.
- proximity of co-ordinates representing their degree of relationship, and the size of coordinates the number of observations. 
Table. 4. Most characteristic words in articles by publication type

\begin{tabular}{|l|c|l|l|}
\hline \multicolumn{1}{|c|}{ PP } & Freq & \multicolumn{1}{c|}{ SP } & Freq \\
\hline Network & 1918 & Communal & 1752 \\
\hline Companies & 1341 & Approach & 1117 \\
\hline Market & 1212 & Librarian & 1101 \\
\hline Business & 1141 & Method & 1031 \\
\hline Media & 1126 & System & 932 \\
\hline Internal & 1099 & Design & 931 \\
\hline Contend & 823 & Knowledge & 885 \\
\hline Software & 764 & Analyze & 828 \\
\hline Custom & 575 & Learning & 825 \\
\hline Advertise & 538 & Participant & 775 \\
\hline
\end{tabular}

\subsection{Top Publications}

Lastly (and briefly), the results shown in Table 5 , concern the $\mathbf{5}$ top publications (schol- arly and professional) in terms of the number of articles published on the topic of social software during the period 2002-2012.

Table. 5. Top Publications on Social Software: Number of Articles by Type

\begin{tabular}{|l|c|l|c|}
\hline \multicolumn{1}{|c|}{ Scholarly Publications } & $\begin{array}{c}\text { No of } \\
\text { Articles }\end{array}$ & \multicolumn{1}{|c|}{$\begin{array}{c}\text { Professional } \\
\text { Publications }\end{array}$} & $\begin{array}{c}\text { No of } \\
\text { Articles }\end{array}$ \\
\hline $\begin{array}{l}\text { CyberPsychology, Behavior \& Social } \\
\text { Networking }\end{array}$ & 57 & New Media Age & 142 \\
\hline $\begin{array}{l}\text { Journal of the American Society for In- } \\
\text { formation Science \& Technology }\end{array}$ & 48 & Advertising Age & 126 \\
\hline Information, Communication \& Society & 29 & InformationWeek & 105 \\
\hline Decision Support Systems & 25 & Computer Weekly & 88 \\
\hline Journal of Information Systems Education & 20 & Computerworld & 77 \\
\hline
\end{tabular}

\section{Conclusions}

The systematic literature analysis presented herein in this paper, employed the principle of lexical analysis, to produce statistical distribution of words and expressions key for the investigation in this work and enable the identification of the general trends in the literature. The paper, also, shed some light on the evolution of social software since the recent advent of social software and web 2.0.

The identification of the most characteristic words gives a general idea of the lines of research on social software in scholarly literature, and of, the areas of focus in the professional literature on these technologies. On another front, the results show a contrast between scholarly literature and professional publications in terms of dealing with the various social software tools. Particularly, the analysis clearly showed that, some types of tools were underaddressed in the scholarly literature. This offers several research opportunities to explore these tools' benefits and shortcomings in the in the different organizational settings. Also, the analysis suggests that much more scientific and academic work is needed to examine the real effects and performance of web 2.0 tools as well as the organizational issues involved with these technologies. This said because, for most of the period studied, social software and web 2.0 tools attracted more attention from the professional publications comparing to the scholarly literature, alt- 
hough, over the past three years 2010-2013, the analysis shows a sign of shifting in the debate on social software to be more scientifically and scholarly oriented.

In general, however, despite the popularity and prevalence of social software tools, yet, paradoxically, interest in the literature seems to be dwindling recently, as in professional and scholarly publications alike, over the last four and two years, respectively, there was a noticeable and steady decrease in the number of articles on social software in both types of publications.

Admittedly, the approach of lexical analysis used for the literature review presented in this paper, involve some limitations. These limitations come from the fact that, as indicated earlier, lexical analysis is limited to determining the frequencies of words and expressions in a certain text. Thus, in the future work, and in order to improve these limitations and to make the literature review more rigorous, deeper and richer; literature will be analyzed using other approaches. One example of these approaches could be the approach of content analysis, by which articles are codified and analyzed according to theoretical categories.

\section{Acknowledgement}

The author thanks Le Sphinx as this research is conducted with their technical support and their software (Sphinx Plus2 - Edition Lexica v. 5.0.1.5).

\section{References}

[1] I. Hamburg, D. Rehfeld, B. Widmaier, Impacts of information technology use in business support agencies services. 15th Triennial World Congress, International Federation of Automatic Control (IFAC), (2002, July), Barcelona, Spain

[2] R. E. Miles, C. C. Snow, G. Miles, Thefuture.Org. Long Range Planning, 2000, 33, 300-321

[3] A. Deverell, A. H. Lassen, The Challenge of Managing Knowledge in Innovative Organizations: Internal Versus External Knowledge Acquisition. In B. Donnellan, T. Larsen, L. Levine \& J. DeGross (Eds.), International Federa- tion for Information Processing (IFIP) TC8 WG 8.6 International Working Conference: Vol. 206. The Transfer and Diffusion of Information Technology for Organizational Resilience (pp. 157-178). (2006, June), Galway, Ireland

[4] K. Blomqvist, J. Levy, Collaboration Capability - A Focal Concept in Knowledge Creation and Collaborative Innovation in Networks. Int. J. Management Concepts and Philosophy, 2006, 2(1), 31-48.

[5] I. Nonaka, A Dynamic Theory of Organizational Knowledge Creation. Organization Science, (1994), 5(1), 14-37.

[6] J. Dron, The Pleasures and Perils of Social Software. Higher Education Academy Subject Centre for Information and Computer Sciences, 2006, 127-131.

[7] M. Grossman, R. V. McCarthy, Web 2.0: Is The Enterprise Ready For The Adventure?. Issues in Information Systems, 2007, VIII(2), 180-185.

[8] S. V. Z. Anria, "The impact of Social Networking 2.0 on organisations", The Electronic Library, 2009, Vol. 27 Iss: 6 pp. $906-918$

[9] C. Allen, Innovation \& Social Software: Presentation, NVHA Innovations Conference, Social Network Media, (2005, February).

http://Web.Lifewithalacrity.Com/Christo phera/Fvha Social_Software Keynote Presentation.Pdf

[10] C. Shirky, A Group Is Its Own Worst Enemy, 2003 http://www.shirky.com/writings/group_e nemy.html

[11] T. O'Reilly, What Is Web 2.0: Design Patterns and Business Models for the Next Generation of Software. Communications \& Strategies, 2007, 1st quarter (65), 17-37.

[12] M. Ahonen, K. Lietsala, Managing service ideas and suggestions - information systems in innovation brokering. Innovation in Services Conference, (2007, April), Tekes, Haas business school, Berkeley, California 
[13] J. Secker, Social software, libraries and distance learners: literature review. (2008), Project Report. LSE, London. (Unpublished).

http://eprints.lse.ac.uk/4058/1/LASSIE_1 it_review\%28LSERO\%29.pdf

[14] L. Zhang, Adoption of social software for collaboration. Doctoral thesis, (2010, October), University of Manchester, UK

[15] D. T. Green, J. M. Pearson, Social software and cyber networks: Ties that bind or weak associations within the political organization?. Proceedings of the 38th Hawaii International Conference on System Sciences (HICSS), (2005, Jan), 117b - $117 \mathrm{~b}$

[16] D. Gendarmi, F. Lanubile, Communitydriven ontology evolution based on folksonomies. In On the Move to Meaningful Internet Systems 2006: OTM 2006 Workshops (pp. 181-188), 2006, Springer Berlin/Heidelberg

[17] K. Stepanyan, R. Mather, J. Payne, Integrating Social Software into Course Design and Tracking Student Engagement: Early Results and Research Perspectives. In World Conference on ELearning in Corporate, Government, Healthcare, and Higher Education (2007, October), (Vol. 2007, No. 1, pp. 7386-7395).

[18] A. Eardley, L. Uden, The Use of 'Web 2.0'and Social Software in Support of Professional Learning Communities. Innovative Knowledge Management: Concepts for Organizational Creativity and Collaborative Design, 204, 2010

[19] A. Soyland, J. Herstad, A tale of two trajectories: bottom-up social software adoption in differing organisational contexts. International Journal of Internet and Enterprise Management, 2011, 7(3), 305-321.

[20] N. Drakos, J. Mann, C. Rozwell, T. Austin, A. Sarner, Magic quadrant for social software in the workplace. Gartner RAS Core Research Note $\mathrm{G}, 2010$
[21] The McKinsey Quarterly, McKinsey Global Survey Results: Building the Web 2.0 Enterprise, 2008

[22] A. P. McAfee, Shattering the myths about enterprise 2.0. IT Management Select, 2009, 15(4), 28

[23] T. Kohn, R. Maier, Using social software in e-learning initiatives in developing countries. In K. Hinkelmann, \& H. Wache, Proceedings of WM2009: 5th Conference on Professional Knowledge Management, 2009, (pp. 32-41).

[24] Y. Kaeomanee, B. M.Rias, R. Perveen, Social software enhanced e-learning system to support knowledge sharing among students: Malaysian Higher Education Institutions Perspectives. In Computer \& Information Science (ICCIS), 2012 International Conference on (Vol. 1, pp. 25-30), (2012, June). IEEE

[25] A. Eardley, L. Uden, The Use of 'Web 2.0'and Social Software in Support of Professional Learning Communities. Innovative Knowledge Management: Concepts for Organizational Creativity and Collaborative Design, 204, 2010.

[26] J. Annala, M. Mákinen, P. Svárd, K. Silius, T. Miilumáki, Online community environment promoting engagement in higher education. Studies for the Learning Society, 2012, 2(2), 75-86

[27] M. Steinhüser, S. Smolnik, U. Hoppe, Measuring the Success of Social Software Adoption in the Firm: Empirical Evidence and Model Design. International Journal of Social and Organizational Dynamics in IT (IJSODIT), 2012, 2(2), 34-47.

[28] G. Avram, At the crossroads of knowledge management and social software. Academic Conferences Ltd, 2005.

[29] J. Vinson, "There is something about social software", Blog, Knowledge Jolt with Jack, 2005 http://blog.jackvinson.com/archives/200 5/04/29/there_is_something_about_socia 1_software.html 
[30] B. R. Katzy, C. J. Stettina, L. P. Groenewegen, M. J. de Groot, Managing weak ties in collaborative work. In Concurrent Enterprising (ICE), 2011 17th International Conference (pp. 1-9). (2011, June), IEEE.

[31] A. Stocker, A. Richter, P. Hoefler, K. Tochtermann, Exploring Appropriation of Enterprise Wikis. Computer Supported Cooperative Work (CSCW), 2012, 140 .

[32] K. Riemer, A. Richter, SOCIALEmergent Enterprise Social Networking Use Cases: A Multi Case Study Comparison. Business Information Systems, Working Paper Series, ISSN 1837-1744, 2012, University of Sydney.

[33] M. Dwivedi, T. P. Shibu, U. Venkatesh, Social software practices on the Internet: Implications for the hotel industry. International Journal of Contemporary Hospitality Management, 2007, 19(5), 415-426.

[34] M. Shailey, "Role of social software tools in education: a literature review", Education + Training, 2009, Vol. 51 Iss: 5/6, pp. $353-369$

[35] S. A. Adams, Revisiting the online health information reliability debate in the wake of" web 2.0": An interdisciplinary literature and website review. 2010, International journal of medical informatics

[36] D. W. Wilson, X. Lin, P. Longstreet, S. Sarker, "Web 2.0: A Definition, Literature Review, and Directions for Future Research", 2011, AMCIS 2011 Proceedings_Paper 368. http://aisel.aisnet.org/amcis2011_submis sions $/ 368$

[37] T. Inagaki, Y. Nakahashi, T. Yabuuchi, H. Tanaka, Consideration of Competencies of the Future Learners from a Review of "Web 2.0" Literature, International Journal, 2012, 6(1), 61-68.

[38] J. Moscarola, R. Bolden, From the data mine to the knowledge mill: Applying the principles of lexical analysis to the data mining and knowledge discovery process. Paper presented at The Second
European Symposium on Principles of Data Mining and Knowledge Discovery, (1998, September), Nantes, France.

[39] J. Moscarola, Contribution of Qualitative Methods to Research in Work and Organizational Psychology: Sphinx Lexica and MCA, (2002, June), Communication to ISSWOV 2002, VARSAW.

[40] M. N. K. Boulos, S. Wheeler, The Emerging Web 2.0 Social Software: An Enabling Suite of Sociable Technologies in Health and Health Care Education. Health Information and Libraries Journal, 2007, 24, 2-23.

[41] Social software. Wikipedia, the free encyclopedia, 2013 http://En.Wikipedia.Org/Wiki/Social_So ftware

[42] M. Koch, CSCW and Enterprise 2.0 towards an integrated perspective. 2008, 21th Bled eConference, eCollaboration: Overcoming Boundaries through MultiChannel Interaction.

[43] J. Secker, C. Lloyd, Libraries, social software and distance learners: The adventures of LASSIE. Health Info on the Internet, 2008, 62(1), 6-8.

[44] S. De Hertogh, S. Viaene, Encouraging the Mindful Consideration of Enterprise 2.0: Design and Deployment of a GDSSSupported Collaborative Strategic Episode. In System Science (HICSS), (2012, January), 45th Hawaii International Conference on (pp. 3858-3868). IEEE.

[45] P. Mechant, A patchwork of online community-based systems: can social software be used to augment online individual social capital?.Observatorio (OBS*), 2009, 3(3)

[46] I. Uitz, Social Media-Is It Worth the Trouble?. Journal of Internet Social Networking \& Virtual Communities, 2012, Vol. 2012 2012, Article ID 313585

http://www.ibimapublishing.com/journal s/JISNVC/jisnvc.html

[47] X. Wang, J. Wang, A Method of Hot Topic Detection in Blogs Using N-gram Model, Journal of Software, 2013, 8(1), 184-191. 
[48] N. Hookway, Entering the blogosphere': some strategies for using blogs in social research. Qualitative Research, 2008, 8(1), 91-113.

[49] M. Ali, H. Lee, The impact of culture and social interaction on weblog design: a Malaysian case. Journal of Enterprise Information Management, 2011, 24(5), 406-423.

[50] G. Swamynathan, C. Wilson, B. Boe, K. Almeroth, B. Y. Zhao, Do social networks improve e-commerce?: a study on social marketplaces. In Proceedings of the first workshop on Online social networks, (2008, August), (pp. 1-6). ACM

[51] M. Ioannidou, E. Raptotasiou, I. Anagnostopoulos, Social Networking and On-Line Communities: Classification and Research Trends. In Semantic Media Adaptation and Personalization (SMAP), (2011, December), 2011 Sixth International Workshop on (pp. 51-56). IEEE

Loay ALTAMIMI has graduated the Faculty of Economic and administrative sciences in 1996. He holds a PhD diploma in Management Information Systems from 2010. He works as assistant professor at the Al-Zaytoonah University of Jordan, Department of MIS. He is also a certified professional trainer (CPT) and a member of the Jordanian Trainers Society (JTS). His research interests include collaborative information systems and web surveys. 